\title{
ACRL seeks volunteers for offices
}

\section{and committees}

\section{The Association needs your help to achieve its goals and objectives.}

W. unteer for appointment to an ACRL standing committee? Are you interested in seeking office in an ACRL section or being considered for appointment to a section committee? If the answer is yes to any of these questions, here is what you need to do.

\section{ACRL President}

The ACRL Appointments and Nominations Committee will nominate candidates for the office of ACRL vice-president/president-elect at the January 1987 Midwinter Meeting of ALA. The election for this office will be held in the spring of 1988 . The winner of the election will serve as vicepresident/president-elect during 1988-89 and as president of ACRL during 1989-90. If you wish to be considered for nomination to this office or if you would like to submit names for consideration, contact the chair of the Appointments and Nominations Committee, Jordan M. Scepanski, Director, Library/Learning Resources, California State University-Long Beach, 1250 Bellflower Boulevard, Long Beach, CA 90840.

\section{ACRL committees}

ACRL has 20 standing committees to which appointments may be made:

- Academic Library Statistics Committee;

- Academic or Research Librarian of the Year Award Committee;

- Academic Status Committee;

- Appointments and Nominations Committee;

- Audiovisual Committee;

- Budget and Finance Committee;
- Conference Program Planning Committee;

- Constitution and Bylaws Committee;

- Copyright Committee;

-Doctoral Dissertation Fellowship Committee;

- Legislation Committee;

- Membership Committee;

- National Conference Committee;

-Planning Committee;

- Professional Association Liaison Committee;

- Professional Education Committee;

- Publications Committee;

- Research Committee;

- Samuel Lazerow Fellowship Committee;

- Standards and Accreditation Committee.

To learn about the areas of responsibility covered by these committees, see the ALA Handbook of Organization 1986-87.

When selected vacancies occur on ACRL standing committees, the Appointments and Nominations Committee recommends to the presidentelect of ACRL the names of members who might fill the vacancies. The president-elect makes the final appointments. If you are interested in being considered for appointment to an ACRL committee, you should complete the ACRL Committee Volunteer Form that is included in this issue of C $\bullet R L$ News and mail it to Jordan M. Scepanski, chair of the Appointments and Nominations Committee, before December 15, 1986.

\section{ACRL section officers}

ACRL has 14 sections (their names are listed later in this article). You will find a description of their areas of responsibility in the ALA Handbook 


\section{ACRL COMMITTEE VOLUNTEER FORM}

If you are interested in serving on an ACRL standing committee, please complete this form and mail it before December 15, 1986, to: Jordan M. Scepanski, Director, Library/Learning Resources, California State University-Long Beach, 1250 Bellflower Boulevard, Long Beach, CA 90840.

If you would like to serve on an ACRL section committee, send this form to the appropriate section vicechair/chair-elect before the ALA Midwinter Meeting.

NAME, TITLE, INSTITUTIONAL ADDRESS

PREFERRED MAILING ADDRESS

DATE OF APPLICATION

NUMBER OF YEARS AS MEMBER OF ALA

ACRL

ACADEMIC BACKGROUND (List institutions, dates of degrees, and relevant subject areas)

\section{PROFESSIONAL ACTIVITIES}

ALA or ACRL Committee Assignments

State and Regional Committee Assignments

ALA or ACRL Offices Held

State and Regional Offices Held

Publications

Other

ACRL COMMITTEE PREFERENCES

RELEVANT BACKGROUND OR EXPERIENCE FOR COMMITTEE ASSIGNMENT

Can you regularly attend the ALA Midwinter and Annual conferences? YES _ NO

(Members of ACRL committees are expected to attend all meetings. Failure to attend two in a row may constitute grounds for removal.)

Please express your major concerns for strengthening the Association of College and Research Libraries on a separate sheet of paper.

If I can't be appointed a full committee member, I would be willing to serve as an intern. 
of Organization.

The chair-elect of a section appoints the chair and members of all section committees when scheduled vacancies on these committees occur. If you would like to be considered for appointment as chair or member of a section committee, fill out the ACRL Committee Volunteer Form and mail it to the chair-elect of the appropriate section (see "People to contact" below) before December 15, 1986.

\section{Editorial boards}

ACRL has five editorial boards:

- the Choice Editorial Board;

- the College \& Research Libraries Editorial Board;

- the College \& Research Libraries News Editorial Board;

- the Publications in Librarianship Editorial Board;

- the Rare Books and Manuscripts Librarianship Editorial Board.

When a vacancy occurs on an editorial board, the editor recommends the name of a person to fill the vacancy. The Publications Committee must approve the recommendation, and the president of ACRL makes the appointment.

If you would like to be considered for appointment to an editorial board, contact the editor of the publication (see "People to contact" below)

Remember that at any given time there are only a limited number of vacancies on ACRL's committees, sections, and editorial boards. If at first you don't succeed in obtaining an appointment, try again. Make yourself known to committee chairs by sitting in on meetings, volunteering to help with committee projects, etc. If committee chairs see that you are interested in the work of their committees, they may recommend your name to the appropriate appointing body when a vacancy occurs.

\section{People to contact}

\section{Anthropology and Sociology Section}

Vice-Chair/Chair-Elect: Lynne M. SchmelzKeil, 29 Curtiss Place, Maplewood, NJ 07040.

\section{Art Section}

Vice-Chair/Chair-Elect: Nancy Allen, Assistant Director for Public Services, Wayne State University Library, Detroit, MI 48202.

\section{Asian and African Section}

Vice-Chair/Chair-Elect: Hideo Kaneko, 182 Knoll Drive, Hamden, CT 06518.

Nominating Committee Chair: Diane E. Perushek, Curator, Gest Oriental Library and East Asian Collections, Princeton University, Princeton, NJ 08544.

\section{Bibliographic Instruction Section}

Vice-Chair/Chair Elect: Barbara J. Wittkopf, Bibliographic Instruction Coordinator, University of Florida Libraries, 114 Library West, Gainesville, FL 32611.

Nominating Committee Chair: Carolyn Kirkendall, 1227 Westmoorland, Ypsilanti, MI 48197.

\section{College Libraries Section}

Vice-Chair/Chair-Elect: Richard Hume Werking, 103 E. Mulberry, San Antonio, TX 78212.

Nominating Committee Chair: Thomas Kirk, Hutchins Library, Berea College, Berea, KY 40404 .

\section{Community and Junior College Libraries Section}

Vice-Chair/Chair-Elect: Eileen Dubin, Stockton State College Library, Pomona, NJ 08240.

Nominating Committee Chair: Joan Hood, 3866 Easton St., Sarasota, FL 33583.

\section{Education and Behavioral Sciences Section}

Vice-Chair/Chair-Elect: Ray Gerke, Assistant Head of Reference Division, Texas A\&M University Library, College Station, TX 77843-5000.

Nominating Committee Chair: Adele S. Dendy, Director, Collis P. Huntington Library, Hampton Institute, East Queen St., Hampton, VA 23668.

\section{Law and Political Science Section}

Vice-Chair/Chair-Elect: Natalie Schatz, Director, Edwin Ginn Library, Fletcher School of Law and Diplomacy, Tufts University, Medford, MA 02155 .

Nominating Committee Chair: Kathleen Gunning, 5518 Cartagena, Houston, TX 77035.

\section{Rare Books and Manuscripts Section}

Vice-Chair/Chair-Elect: Alice D. Schreyer, Special Collections, University of Delaware Libraries, Newark, DE 19717-5267.

Nominating Committee Chair: Anna Lou S. Ashby, Pierpont Morgan Library, 29 E. 36th St., New York, NY 10016.

\section{Science and Technology Section}

Vice-Chair/Chair-Elect: Katherine S. Chiang, Computerized Data Services Librarian, Albert R. Mann Library, Cornell University, Ithaca, NY 14853-4301.

\section{Slavic and East European Section}

Vice-Chair/Chair-Elect: Cheryl A. KernSimirenko, Slavic and Women's Studies Librarian, 458 Bird Library, Syracuse University, Syracuse, NY 13210.

Nominating Committee Chair: George S. Toth, Slavic and East European Cataloger, Shared Cata$\log /$ Slavic Section, Library of Congress, Washington, DC 20540. 


\section{University Libraries Section}

Vice-Chair/Chair-Elect: Barry B. Baker, Assistant Director for Technical Services, University of Georgia Libraries, Athens, GA 30602.

Nominating Committee Chair: Joseph J. Branin, Director, Humanities and Social Science Libraries, University of Minnesota, Minneapolis, MN 55455.

\section{Western European Specialists Section}

Vice-Chair/Chair-Elect: Assunta S. Pisani, Administrative Head, Collection Development Department, Harvard College Library, Harvard University, Cambridge, MA 02138.

\section{Women's Studies Section}

Co-Chairs: Lori Goetsch, Information/Reference Department, Michigan State University Library, East Lansing, MI 48824-1073; Susan
Searing, Women's Studies Librarian, 112A Memorial Library, 728 State St., Madison, WI 53706.

\section{Editorial Boards}

Choice Editor: Patricia Sabosik, Choice, 100 Riverside Center, Middletown, CT 06457.

College \& Research Libraries Editor: Charles Martell, Associate University Librarian for Public Services, California State University, 2000 Jed Smith Drive, Sacramento, CA 95819.

College \& Research Libraries News Editor: George M. Eberhart, ACRL/ALA, 50 E. Huron St., Chicago, IL 60611-2795.

ACRL Publications in Librarianship Editor: Arthur P. Young, Dean of Libraries, University of Rhode Island, Kingston, RI 02881.

Rare Books and Manuscripts Librarianship Editor: Ann S. Gwyn, Milton S. Eisenhower Library, Johns Hopkins University, Baltimore, MD 21218.

\section{ACRL chapters}

\section{Meet ACRL's local representatives.}

\begin{abstract}
A
CRL chapters serve as channels between academic and research librarians and the ACRL Headquarters. Thirty-seven regional and state ACRL chapters now cover forty-one states and one Canadian province, and provide opportunities for local participation for over 9,000 ACRL members who live within those areas. To find out how you can participate, contact the chair of the chapter nearest to you.

If you would like to start a chapter in your region, contact Linda Woo, Chair, Chapters Council Committee for New ACRL State Chapters, 1451 Garfield St., Denver, CO 80206.
\end{abstract}

Alabama Chapter (est. 1986)

To be appointed.

Arizona Chapter (est. 1982)
Jean D. Collins, University Librarian, Cline Library, Northern Arizona University, NAU Box 6022, Flagstaff, AZ 85011-0051.

\section{California Chapter (est. 1979)}

Marion Peters, Head Librarian, Chemistry Library, University of California, Los Angeles, CA 90034 .

\section{Colorado Chapter (est. 1983)}

John Garralda, Denver Public Library, 1357 Broadway, Denver, CO 80203.

\section{Delaware Valley Chapter (est. 1969)}

Judith M. Feller, Documents Librarian, East Stroudsburg University, East Stroudsburg, PA 18301 .

Florida Chapter (est. 1978) 